\title{
Max Planck supports research in east as cost of reunification climbs
}

Halle. It is now clear that scientists in western Germany will have to pay part of the cost of reintegrating their scientific colleagues from the east. But recent decisions by the Max Planck Society to fund more than 30 research groups in the former East Germany, including four new research institutes, has begun to restore confidence that the research enterprise in the new Germany will be strengthened by reunification.

Despite earlier predictions that research in East Germany might be too low in quality to be worth saving, detailed evaluations of eastern research by the society and by the German research advisory council (the Wissenschaftsrat) have highlighted pockets of research excellence in the east. Reversing its previous policy, the society has decided to fund two new physics institutes and two for biological research when money is available. Many smaller projects in universities are already being funded.

The Halle Institute for Solid State Physics and Electron microscopy has become the first Max Planck Institute in the former DDR. It survived a restructuring. The Max Planck Society, which funds 56 large basic science research institutes in western Germany, was originally dubious of bailing out eastern research. It was concerned that lingering attitudes of the communist regime might somehow 'infect' its own research philosophy. Pessimism had been fuelled by attempts to evaluate East German science before the Berlin Wall came down in 1989. Obscured by Iron-Curtain secrecy, these had indicated that its level might be no higher than Albania's.

But prejudices began to fall away when early results of the detailed evaluations commissioned by the research advisory council in summer 1990 highlighted pockets of research excellence in the east. This coincided with the appointment in June 1990 as president of the society of Hans Zacher. Zacher is more sympathetic than his predecessor to the plight of the east.

With a more optimistic outlook, the society set up its own evaluation committees and, in cooperation with the research advisory council, identified the areas of research it wished to support. By the end of last year, these included 28 individual groups in universities whose work will be supported financially for five years (see sidebar) and two institutes - the Halle institute reconstituted in January and the Institute for Colloid and Interface Research, to be established within the next few years at a location yet to be decided.

The former Institute of Solid State Physics and Electron microscopy in Halle pioneered the electron microscopic decoration technique which allows the properties of crystal structures to be correlated with their defects. And with its light still well hidden under a bushel, the institute was also for many years ahead of the world in the development of electron microscopes. According to Johannes Heydenreich, vice-director of the institute since 1962 and now one of three in-house directors of the newly created institute, success was due to the working environment created by its first director, Heinz Bethge, who retired in 1985. "He created a unique atmosphere of support and cooperation", says Heydenreich. "He had a classically open-minded approach to research.

\section{Social sciences found worth funding}

Munich. Surprisingly strong research in the social sciences by scientists in eastern Germany has forced the government to examine how the humanities should be funded in a unified Germany.

The finding that the former DDR was doing good work in subjects ranging from linguistics to contemporary history and history of science came as West Germany was debating how to strengthen its own, long-neglected humanities programmes. To solve both problems, the German research advisory council (the Wissenschaft) appointed the Max Planck Society as trustee to seven identified groups in the East whose research was recognized as being of high quality. The committee appointed to oversee the centres will make recommendations on how the humanities might best be fostered in the future in a unified Germany.

Hans Zacher, president of the society, does not expect the committee to support the research advisory council's original suggestion to set up a society for social sciences analogous to the Max Planck, which directs centres for science research and receives half its funding from the federal government and half from regional governments. "It's more likely that each group will be affiliated to a university but receive special funding from an organization like the German research council (DFG)", he says.
And, unusually for the DDR, if a senior staff member was invited to a conference in the West, an infrequent enough event in itself, he insisted that one of the younger scientists go along."

But a certain price was exacted for this success. Like all research institutes in East Germany, the Halle institute was forced to spend at least half its time solving industrial problems. And each institute had to generate a certain proportion of its funding from industrial sources. In this way, the state ensured a firm and very direct relationship between fundamental and applied research.

Pressure to raise industrial income intensified as the economy of the DDR began to collapse in the 1980s, so that, by 1989 , eastern institutes were raising half their running costs this way. The successful Halle institute was even returning a surplus to the state.

But such direct support for industry had no place in western research plans, so that evaluation committees set about identifying the redundancies eastern scientists had been fearing. In the event, most institutes

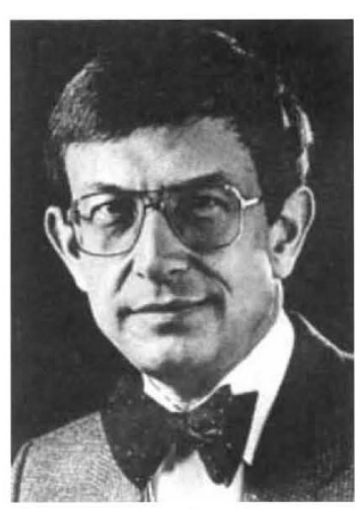

Research Minister Heinz Riesenhuber have shed be-

tween a third and one half of their staffs, but Halle is again exceptional.

Max Planck took on 100 staff (including 45 scientists), although one-quarter were hired on three-year contracts. A group of 15 are now sponsored by Freiburg's Fraunhofer Institute, which specializes in applied research in microstructure technology. Five scientists have set up an independent micro diagnostic business with temporary assistance from the German Research Council (DFG). Nine are working on short-term grants from the German research councils and the rest left voluntarily for jobs in the west.

Heydenreich, whose lack of political influence with the old regime had caused him to be by passed as Bethge's successor, was made the first of three directors of the new institute. He will be joined by two West Germans: Jürgen Kirschner from the Free University in Berlin and Ulrich Gösele from Duke University in North Carolina, whose interest in conducting research at Halle has 
outweighed the disadvantages of a lower standard of living.

Setting up the Halle institute has so far cost the Max Planck Society DM9.8 million (US\$6 million). Half of this money is provided by the federal government and the other half by the eastern states. The funding is independent of Max Planck's 1992 DM1,400 million budget, split equally between regional governments in the west and the federal government. In some respects the Halle institute was added to the fold on the cheap. Salaries are only 60 per cent of those in the west, and it will be a few years before they will be equalized. Although pay is still better than under the DDR, the cost of living is rising rapidly in the east and the staff are keen for wage parity. Last week, Bonn announced that rents (which are state controlled in Germany) in eastern states are to be doubled by the end of the year. The second Max Planck institute planned in eastern Germany will be of a similar size to Halle. Three research groups, from Adlershof and Teltow near Berlin and from Freiberg in Saxony, will be brought together to work on interdisciplinary projects investigating the structure, dynamics and physical and chemical properties of colloidal systems. Its location will be decided this summer.

The society is also keen to safeguard two further areas of research excellence in the former DDR. In March it announced its intention to support two further institutes one in infection biology and the other in plant molecular physiology - as soon as money becomes available.

But when will that be? And will the west accept the increasingly high price of supporting the political ideals of those who wish to raise east German standards to their own? In the sudden political and economic uncertainty of Germany, these questions are difficult to answer.

Despite the special funds that have been set up to support research in the former DDR, it is clear that the government's persistent denial that the west must make sacrifices has lost credence. In fact, last week Research Minister Heinz Riesenhuber announced that 100 jobs would be lost in large research centres in the west so that money can be redirected "to bring the level of research in East Germany to levels in West Germany as quickly as possible." It was the government's first admission that there will be scientific losers as well as winners in its effort to reunite the formerly divided country. And like the DFG, the 5 per cent annual budget increase to which the society is committed until 1995 will be swallowed up by staff costs following the inflationary public sector wage settlement earlier this month (see Nature 357, 182; 1992).

The spirit of Germany may be willing, but it is becoming increasingly difficult to maintain the extraordinary speed and efficiency that has marked the first few years of reintegration of East German science.

Alison Abbott

\section{Max Planck funds small projects}

Munich. In the former DDR, research was mainly conducted in the 60 research units run by the National Academy of Science and concentrated around Berlin. Relatively little activity took place at universities, the traditional home for innovative research in West Germany.

But this situation is changing. The government's decision in June 1990 to harmonize research policy prompted the Max Planck Society, which normally sponsors only large-scale research that cannot be conducted within universities, to offer temporary support to de serving groups.

To protect research identified as very strong by evaluation committees of the society and the German Research Council (DFG), and to strengthen future university research, Max Planck is funding and administering 28 research groups in areas ranging from physics, to biochemistry to ecology. Funding will be restricted to five years. If the research develops well during this time, the universities will be expected to take over the financing directly.

The jewel in the eastern crown is Gunther Fischer's group from Halle. In the late 1980 s, Fischer was the first to identify and purify cis-trans peptidylprolyl isomerase, an enzyme which catalyses a rate-limiting step in protein folding. This enzyme was subsequently shown to be identical to cylcophilin, which binds the immunosuppressant drug cyclosporin, and it has helped to open up an important new field of biochemical immunology.

A special fund for these projects has been provided by the federal and regional governments, who normally split the costs of running the Max Planck Society. But the 1992 allocation of only DM130,000 (US $\$ 80,000$ ) per researcher, amounting to DM98,500 million in total, has been criticized as inadequate by Hans Zacher, president of Max Planck. Zacher would like to raise the average grant to DM180,000 in 1993.A.A.

\section{Researchers look beyond UNCED}

London. As diplomats, politicians and representatives from non-governmental organizations gather next week in Rio de Janeiro for the United Nations Conference on Environment and Development (UNCED), the environmental researchers whose work set the agenda for what is popularly known as the Earth Summit are concerned about what will happen afterwards.

"The critical period is what follows UNCED, and scientists are concerned about maintaining whatever momentum the conference has generated," said Jim Dooge, president-elect of the International Council of Scientific Unions (ICSU). "The key thing, post-UNCED, is science forging new partnerships with business, between the natural sciences and social sciences, and with policy makers."

Although some researchers bemoan the lack of scientific input into the conference itself, most recognize that Rio will be crowded enough over the next three weeks without them. The discussions that will take place will be largely political - UNCED is not now a scientific conference, if it ever was - and more than 100 heads of state are expected to address the delegates.

Although science may have been absent from the proceedings, environmental researchers have had an impact on the substantial issues being addressed. Bodies such as the Intergovernmental Panel on Climate Change and ICSU's ASCEND-21 meeting

\section{(An Agenda of Science for Environment} and Development into the 21st Century) have submitted weighty documents to the conference, as have individual scientific groups. Last week, for instance, the University of Oxford's Environmental Change Unit published a report entitled "Climate Change and World Food Supply". In addition, the efforts of researchers are represented in the various texts to be considered by UNCED delegates, and even if they are not adopted, it is hoped that their contribution will be recognized.

"Science has had a considerable input", says Tim O'Riordan, of the Centre for Social and Economic Research in the Global Environment, University of East Anglia, "but it is a matter of whether UNCED understands that, and if the documents produced from the conference reflect that. If that is not the case, then science will be damaged."

One way to bring that about is for Maurice Strong, secretary general of UNCED, to set up an office at the UN to set the agenda for future scientific work, including a roadmap that points out the gaps in existing knowledge and to areas that are most important. Although scientific programmes will undoubtedly continue in the wake of UNCED, researchers believe that the conference itself will heighten awareness of the issues and put pressure on governments to in crease their monitoring of environmental problems.

Ian Mundell 